\title{
The Utilization of Microbial Inoculants Based on Irradiated Compost in Dryland Remediation to Increase The Growth of King Grass and Maize
}

\author{
T.R.D. Larasati ${ }^{\star}$, N. Mulyana and D. Sudradjat \\ Center for Isotopes and Radiation Application, National Nuclear Energy Agency \\ Jl. Lebak Bulus Raya No.49, Jakarta 12070, Indonesia
}

\section{ARTICLE INFO}

\section{Article history:}

Received 17 March 2015

Received in revised form 28 October 2015 Accepted 28 October 2015

\section{Keywords:}

Remediation

Microbial inoculants

Dryland

King grass

Maize

\begin{abstract}
A B S T R A C T
This research was conducted to evaluate the capability of functional microbial inoculants to remediate drylands. The microbial inoculants used consist of hydrocarbon-degrading microbial inoculants and plant-growth-promoting microbial inoculants. Compost-based carrier was sterilized by a gamma irradiation dose of $25 \mathrm{kGy}$ to prepare seed inoculants. The irradiated-compost-based hydrocarbondegrading microbial inoculants and king grass (Pennisetum purpureum Schumach.) were used to remediate oil-sludge-contaminated soil using in-situ composting for 60 days. The results showed that they could reduce THP (total petroleum hydrocarbons) by up to $82.23 \%$. Plant-growth-promoting microbial inoculants were able to increase the dry weight of king grass from 47.39 to $100.66 \mathrm{~g} / \mathrm{plant}, \mathrm{N}$ uptake from 415.53 to $913.67 \mathrm{mg} /$ plant, and P uptake from 76.52 to $178.33 \mathrm{mg} / \mathrm{plant}$. Cow dung and irradiated-compost-based plant-growth-promoting microbial inoculants were able to increase the dry weight of maize (Zea mays L.) from 5.75 to 6.63 ton/ha $(12.54 \%)$ and dry weight of grain potential from 5.30 to 7.15 ton/ha $(35.03 \%)$. The results indicate that irradiated-compost-based microbial inoculants are suitable for remediating a dryland and therefore increase potential resources and improve the quality of the environment.
\end{abstract}

(C) 2016 Atom Indonesia. All rights reserved

\section{INTRODUCTION}

The term forest encroachment refers to the land conversion and forest modification [1]. A region or forest buffer zones is required to ensure the protection and preservation of forests. Teak (Tectona grandis L.) forests in the District of Ngasem, Bojonegoro Regency, East Java Province are used by the local community as agricultural land with a low production capacity. The dryland cropping sytem if carried out in conventional manner has a potential to cause erosion and mudslides that often occur in some areas in Bojonegoro. Dryland cropping systems and tillage are unsuitable soil conservation rules which increase erosion and reduce land productivity [2].

\footnotetext{
${ }^{*}$ Corresponding author.

E-mail address: tretno@batan.go.id

DOI: http://dx.doi.org/10.17146/aij.2016.477
}

The mitigation of dryland degradation needs to be comprehensive because an increase in degraded lands includes a simultaneous unity between biophysical, socio-economic, and cultural factors [2].

Farmers from communities around the teak forests have traditionally extracted oil from old oil wells located in Kedewan, Cepu, Blora. This activity resulted in spills and oil sludge. Oil sludge is formed from the collection and deposition of oil contaminants that cannot be reused in the production process. The main content of the oil sludge is hydrocarbons, which can be treated with bioremediation process. Bioremediation of oil-sludge-contaminated soil can be done by adding nonindigenous microbes which degrade high-potential hydrocarbons (bioaugmentation) or with the addition of nutrients to improve the ability of indigenous microbes (biostimulation) [3]. 
The bioremediation process can be done through composting [4]. The addition of compost, as well as the source of inoculants, is also a source of nutrients in the soil which will accelerate the degradation of hydrocarbon pollutants [5].

Compost is a product of the decomposition of organic waste. Its renewable base materials are available in abundance, and the material's potential for use as a soil improvement agent is great. Adding compost into the soil will increase the water holding ability, promote the formation and stabilization of soil aggregates, and increase the infiltration of water that contribute to the reduction of soil erosion [6]. The added organic matter to the soil can also support changes in $\mathrm{pH}$ values and increase the cation exchange ability, so as to improve the activity and biodiversity in the soil and increase the efficiency of the supply of nutrients to plants [7]. Compost is used as a carrier material capable of sustaining microbial growth and survival during storage and distribution in the field. To prevent competition between the target microbes and other microbes in the compost, the carrier was then sterilized [8]. One of the cleaning methods is sterilization of microorganism carrier with gammaray irradiation. Previous studies obtained the irradiation dose for carrier sterilization as $25 \mathrm{kGy}$. This radiation dose is able to reduce the concentration of indigenous microorganisms to $<10^{1} \mathrm{cfu} / \mathrm{g}$, allowing the compost to be stored for up to 6 months [9].

This study aims at supporting the development of the potential dryland resource through application of appropriate remediation technologies using irradiated compost based on local sources of organic matter and selected functional inoculant consortia. The results are expected to be part of efforts to improve environmental quality, develop potential dryland resources, and empower forest communities.

\section{EXPERIMENTAL METHODS}

The activities of the research were conducted in laboratory-scale and field trials, which included preparation and utilization of irradiated-compostbased microbial inoculants, respectively. The activities of dryland remediation were carried out in the Ngasem district, Bojonegoro, East Java province. Maize plant was used as the bioindicator of the utilization of irradiated-compost-based microbial inoculants in dryland remediation. Meanwhile, the activities of oil-sludgecontaminated soil remediation were carried out in traditional oil exploration in an old wells area in
Kedewan district, Cepu, Blora, Central Java province. The king grass was used as the bioindicator of the utilization of irradiated-compost based microbial inoculants in the remediation of oilsludge-contaminated soil.

\section{Preparation of irradiated-compost-based functional microbial inoculant}

Microbial isolates used to prepare plant growth-promoting inoculants consisted of nitrogenfixing bacteria (KDB2), phosphate-solubilizing bacteria (KLB5, BM5, KLBN1) and organicmaterial-decomposing fungi (KLF6, RK1). Isolates were used to prepare hydrocarbon-degrading inoculants. Those isolates included BMC2, BMC4, BMC6, FMC2, and FMC6 which were selected from petroleum-sludge-contaminated soil. To maintain the viability of the target, a compost-based carrier was used. The carrier exhibited a $\mathrm{pH}$ of 7 , a water holding capability of $189 \%$, a moisture content of $24 \%$, an organic matter content of $44 \%$, an organic $\mathrm{C}$ content of $16 \%, \mathrm{C} / \mathrm{N}$ ratio of 13 , and a $\mathrm{P}_{2} \mathrm{O}_{5}$ content of approximately $1.69 \%$. The compostbased carrier materials were sterilized by gamma irradiation with a dose of $25 \mathrm{kGy}$, which radiation source was Co-60 of a type 4000A gamma chamber. The dose rate used was $2.1 \mathrm{kGy} / \mathrm{h}$, and the irradiation was performed at room temperature. In order to obtain two different types of microbial inoculants, $90 \mathrm{~g}$ of sterilized carrier material was inoculated with $10 \mathrm{ml}$ of liquid culture containing a well-composed volume ratio of microbial consortia. Both types of functional microbial inoculants contained $10^{9} \mathrm{cfu} / \mathrm{g}$ live cells. They were then incubated at $28^{\circ} \mathrm{C}$ for 14 days before distribution to the remediation locations. There were no physical and/or chemical changes to the microbial inoculants in the following 14 days of incubation.

\section{Utilization of irradiated-compost-based microbial inoculants in dryland remediation}

The activities of dryland remediation was conducted upland of the teak forest at Persil 3, Ngasem district, Bojonegoro, East Java. Functional and plant-growth-promoting microbial inoculants were used as a bioactive material to prepare biofertilizer. The raw fertilizer materials consisted of manure and feed residual-straw which were available in-situ at the remediation site. One hundred grams of irradiated-compostbased microbial inoculants were activated by $5 \%$ molasses in a 5-liter solution for 24 hours. The solution was then added with $40 \mathrm{~kg}$ of manure, 
$8 \mathrm{~kg}$ of feed residual-straw, and $2 \mathrm{~kg}$ of dolomite. Dryland remediation was intended to improve the growth and yield of maize (Zea mays L.) (P21 variety). Maize was planted between teak trees (Tectona grandis L.) at site I (1 year) and site II (2 years). Experiments were conducted at both locations, consisting of $\mathrm{A}=100 \% \mathrm{NPK}$ as control and $\mathrm{B}=75 \% \mathrm{NPK}+\mathrm{PBO}$ (biofertilizer) as treatment, with three replications in each plot measuring $500 \mathrm{~m}^{2}$. A biofertilizer dosage of $50 \mathrm{~kg} / \mathrm{plot}$ or $1000 \mathrm{~kg} / \mathrm{ha}$ was given at the experimental location while handling land for the second time. The dosage of the 100\% NPK fertilizer with a 15:15:15 ration of Phonska fertilizer was $10 \mathrm{~kg} / \mathrm{plot}$ or $200 \mathrm{~kg} / \mathrm{ha}$. The dosage was given on day 1 and day 30 since the maize was planted.

\section{Remediation of oil-sludge-contaminated soil by irradiated-compost-based microbial inoculants}

The activities of remediation of oil-sludgecontaminated soil were carried out in an area of traditional oil exploration sites in Cepu, Blora, Central Java. Dryland remediation of hydrocarboncontaminated soil was conducted by in-situ composting and king grass (Pennisetum purpureum Schumach.) planting. In-situ composting was carried out during a two-month period before king grass stem cuttings. Irradiated-compost-based microbial inoculants of hydrocarbon-degrading bacteries and sawdust were mixed in the in-situ composting process [10]. A quantity of $300 \mathrm{~g}$ of irradiated-compost-based functional microbial inoculants was activated with 30 liters of $5 \%$ molasses solution for 24 hours. The mixture was then inoculated into $60 \mathrm{~kg}$ of sawdust and incubated for 14 days. After incubation, irradiated-compost based microbial inoculants were used for composting the oil-sludge contaminated land on a plot of $150 \mathrm{~m}^{2}$. The mixture of $60 \mathrm{~kg}$ sawdust and $3.6 \mathrm{~kg}$ of NPK fertilizer was spread on the surface of the oil-sludge-contaminated land on plots of $150 \mathrm{~m}^{2}$. Then, the fertilizer was mixed until evenly combined with the depth of $20-30 \mathrm{~cm}$. The plot is divided into six subplots, each sized $20 \mathrm{~m}^{2}$, spaced by about 1 meter. To maintain the condition of the composting process, the middle of a plot was mounded with a height of about $20 \mathrm{~cm}$ and covered with plastic. Watering and ground reversing were performed at 1 and 2 months after the hydrocarbon degrading-functional microbes were inoculated. The king grass planting trial was performed in-situ post composting of oil-sludge-contaminated land. The plots were grouped into $\mathrm{A}=$ control (without microbial inoculants) and $\mathrm{B}=$ with plant-growthpromoting functional microbial inoculants added with three replications in plots of $20 \mathrm{~m}^{2}$, respectively. Into both A and B were also given 300 $\mathrm{g}$ of NPK per plot. To an amount of $50 \mathrm{~g}$ of activated microbial inoculants, 5 liters of $5 \%$ molasses solution was added for 24 hours. The result of this activation was diluted with 25 liters of water and spread on the surface of the B plot; afterward, secondary land handling was carried out to prepare the plot of king grass planting with a size of $50 \times 100 \mathrm{~cm}$.

The evaluation was conducted on the parameters of soil and bioorganic fertilizer quality, crop yield of maize (Zea mays L., P21 variety), and crop yield of king grass (Pennisetum purpureum Schumach.). The observed parameters of soil quality consist of $\mathrm{pH}$, organic matter, organic $\mathrm{C}, \mathrm{N}$ total, $\mathrm{C} / \mathrm{N}$, and total petroleum hydrocarbon (TPH). Additionally, the parameters of bioindicator yield include the weights of dry stover, wet stover, dry cob, and 100 seeds/cob; they also include and the potential yield of wet stover, potential yield of dry stover, potential yield of dry seeds, shoot height, wet shoot weight, dry shoot weight, $\mathrm{N}$ uptake, and $\mathrm{P}$ uptake. The experimental design used was a completely randomized design. The experimental data was then analyzed by ANOVA (Analysis of Variance) followed by Duncan's test if any significant difference occurred among the treatments.

\section{RESULTS AND DISCUSSION}

\section{Effect of gamma radiation on compost- based- carrier sterilization}

The production of microbial inoculants requires a carrier that is able to sustain the survival of those microbes during periods of storage and distribution [11]. In order to prevent competition between the target microbes with other microbes in the environment that is rich in nutrients, carrier sterilization is required [12]. Application of the 4000A Gamma Chamber for sterilization performed with a dose of $25 \mathrm{kGy}$ was able to reduce the original microorganisms of compost-based carrier material to an undetectable $10^{1} \mathrm{cfu} / \mathrm{g}$, as shown in Table 1 . The sterilization process using gamma ray irradiation does not change the physical and chemical properties of the carrier material and does not produce substances that are toxic to some microbes [9]. 
Table 1. Effect of gamma irradiation on Total Contents of Fungi and Aerobic Bacteria

\begin{tabular}{llcc}
\hline \multirow{2}{*}{ No } & \multirow{2}{*}{ Parameter } & \multicolumn{2}{c}{ Gamma Irradiation, kGy } \\
\cline { 3 - 4 } & & $\mathbf{0}$ & $\mathbf{2 5}$ \\
\hline 1 & Aerob Bacterial Total, cfu/g & $5.95 \times 10^{7}$ & $<10^{1}$ \\
2 & Fungi Total, cfu/g & $1.16 \times 10^{8}$ & $<10^{1}$ \\
\hline
\end{tabular}

\section{Soil characteristics in the experimental field}

The dryland of teak forest at Persil 3 Ngasem district, Bojonegoro has a neutral $\mathrm{pH}$ (6.6 to 7.5), moderate organic $\mathrm{C}(2-3 \%)$, high $\mathrm{N}$ (0.51 to 0.75$)$, low $\mathrm{C} / \mathrm{N}(<5)$, and low $\mathrm{P}_{2} \mathrm{O}_{5}(<4$ ppm $\mathrm{P})$ as shown in Table 2. According to these criteria, very low $\mathrm{P}$ $\left(\mathrm{P}_{2} \mathrm{O}_{5}\right)$ is suspected to be associated with the less optimal carrying capacity of the land for crop growth and yield. Therefore, dryland remediation using functional microbial inoculants was expected to be able to improve productivity of the dryland when the inoculants contained phosphate solubilizing bacteria [8], since phosphate is needed for plant growth. East Java is one of the centers of national maize production, so the remediation was applied on drylands of maize (Zea mays L.).

Table 2. Soil Characteristics at the Bojonegoro and Cepu sites

\begin{tabular}{lllll}
\hline No & Parameter & \multicolumn{2}{c}{ Dryland at Bojonegoro } & \multicolumn{1}{c}{$\begin{array}{c}\text { Oil sludge } \\
\text { contaminated } \\
\text { soil at Cepu }\end{array}$} \\
\cline { 3 - 5 } & Sitei I & Site II & $7.67 \pm 0.13$ \\
\hline 1 & $\mathrm{pH}$ & $7.12 \pm 0.13$ & $7.17 \pm 0.08$ & \\
2 & Organic & $11.50 \pm 0.53$ & $11.82 \pm 0.79$ & $13.86 \pm 1.03$ \\
& Material, \% & & & \\
3 & $\mathrm{C}, \%$ & $2.62 \pm 0.18$ & $2.64 \pm 0.16$ & $5.54 \pm 0.11$ \\
4 & $\mathrm{~N} \mathrm{Total}, \%$ & $0.54 \pm 0.20$ & $0.54 \pm 0.11$ & $0.14 \pm 0.02$ \\
5 & $\mathrm{C} / \mathrm{N}$ & $4.95 \pm 0.33$ & $4.90 \pm 0.30$ & $40.49 \pm 0.78$ \\
6 & $\mathrm{P}_{2} \mathrm{O}_{5}, \mathrm{ppm} \mathrm{P}$ & $1.18 \pm 0.18$ & $1.24 \pm 0.15$ & $0.55 \pm 0.09$ \\
7 & $\mathrm{TPH}, \mathrm{g} / \mathrm{kg}$ & - & - & $105.06 \pm 7.93$ \\
\hline
\end{tabular}

The dryland of oil-sludge-contaminated soil in traditional oil exploration sites (Cepu) has a slightly alkaline $\mathrm{pH}$ (7.6 to 8.5$)$, high organic $\mathrm{C}(>5 \%)$, low $\mathrm{N}(0.1-0.2 \%)$, high $\mathrm{C} / \mathrm{N}$ ratio $(>25)$, and low $\mathrm{P}_{2} \mathrm{O}_{5}(<4$ ppm $\mathrm{P})$ as shown in Table 2 . Characteristics of these physicochemical properties are suspected to be associated with spills or contamination by oil sludge in the ground. This condition requires gradual remediation efforts for the improvement of soil quality parameters, the degradation of hydrocarbons and toxic potential, and the recovery of the productive functions of land $[13,14]$. Due to the low carrying capacity and high toxic potential of the land, the early stages of remediation efforts were conducted by composting at the target location (in-situ composting) and the following stage was through planting of king grass (Pennisetum purpureum Schumach.) as a nonfood crop $[15,16]$.

\section{Effects of dryland remediation on the growth of maize plant}

Remediation with bioorganic fertilizer (PBO) was conducted in two teak forest rejuvenation areas in Persil 3 Bojonegoro to improve the function of productive dryland forest buffer. PBO is an organic fertilizer enriched with microbial consortia inoculants to enhance the growth and yield of $100 \mathrm{~g}$ functional microbial consortia inoculants was used to produce approximately $50 \mathrm{~kg}$ bioorganic fertilizer that consists of $80 \%$ manure, $16 \%$ cattle feed residual straw, and $4 \%$ dolomite. The obtained bioorganic fertilizer has appropriate quality parameters according to the Regulation of Agricultural Ministry No. 28/ Permentan/ SR.130/S/2009 on the minimum technical requirements of organic fertilizers as shown in Table 3.

Table 3. Quality of Bioorganic-Fertilizer-Based Local Organic Matter

\begin{tabular}{clll}
\hline No & Parameter & $\begin{array}{c}\text { Bio-organic } \\
\text { Fertilizer }\end{array}$ & $\begin{array}{c}\text { Technical } \\
\text { Requirements }\end{array}$ \\
\hline 1 & $\mathrm{pH}$ & $7.08 \pm 0.14$ & $4-8$ \\
2 & WHC, $\%$ & $191 \pm 12.73$ & - \\
& Organic & $34.47 \pm 1.70$ & - \\
3 & Material, \% & $22.75 \pm 0.85$ & $\geq 12$ \\
4 & $\mathrm{C}, \%$ & $1.40 \pm 0.08$ & $<6$ \\
5 & $\mathrm{~N}$ Total, \% & $16.56 \pm 0.62$ & $15-25$ \\
6 & $\mathrm{C} / \mathrm{N}$ & $0.77 \pm 0.06$ & $<6$ \\
7 & $\mathrm{P}_{2} \mathrm{O}_{5}, \%$ & & \\
\hline
\end{tabular}

Bioorganic fertilizer $(50 \mathrm{~kg})$ was applied to $500 \mathrm{~m}^{2}$ of the observed plot when secondary land handling was conducted. The experimental land was left without any treatment for two days before planting corn seeds. Plot $\mathrm{A}$ as control was given $100 \%$ NPK fertilizer or about $200 \mathrm{~kg} / \mathrm{ha}$ whereas plot B was given 75\% NPK fertilizer in day 1 and day 30 after planting.

Remediation applications enriched with organic fertilizer microbial inoculants consortium functional affect the improvement of the appearance of the growth and yield of maize (Zea mays L.) variety P21 on dryland forest buffers. In Fig. 1, it seems that there are fewer teak trees at plot B (site I) than at plot A (control). This is since the growth of teak plants at plot B is less evenly distributed than at plot A. Corn crop between the teak (Tectona grandis L.) trees aged 1 year (site I) and 2 year (site II) shows better results than the control at both sites. 


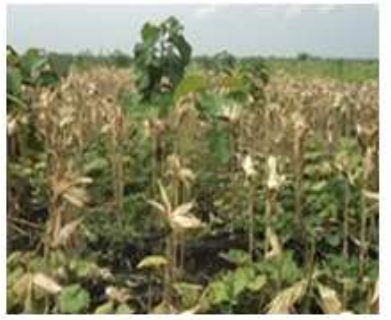

Control (A) at Site I

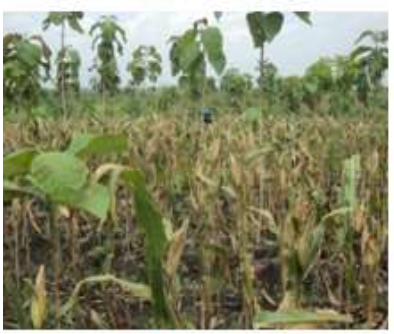

$\operatorname{Control}(\mathrm{A})$ at Site II

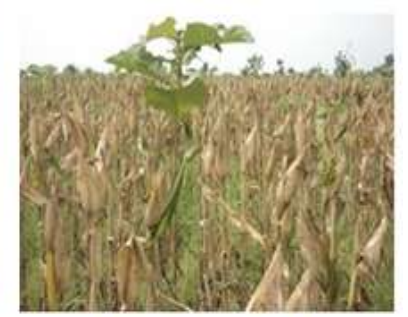

Remediation (B) at Site I

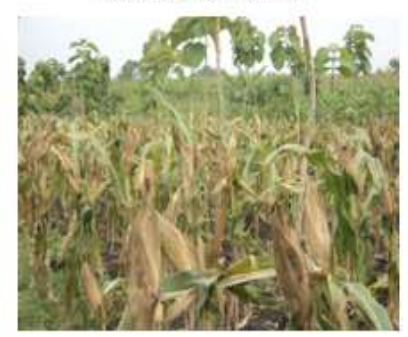

Remediation (B) at Site II
Fig. 1. Performance of Maize plants between one- year-old teaks (Site I) and two-year-old teaks (Site II).

From ANOVA test, it was found that remediation using $50 \mathrm{~kg} / 500 \mathrm{~m}^{2}$ biofertilizer or 1 ton/ha gave significant difference $(\mathrm{p}<0.05)$ on the weights of dry stover, wet stover, dry cob, and 100 seeds/cob, and potential yields of wet stover, dry stover, and dry seeds in crop yield of maize (Zea mays L.) variety P21 on the dryland of forest buffer as shown in Table 4.

Table 4. The Growth of Maize Plants between One-Year-Old Teaks (Site I) and Two-Year-old Teaks (Site II)

\begin{tabular}{|c|c|c|c|c|c|}
\hline \multirow{2}{*}{ No } & \multirow{2}{*}{ Paramaeter } & \multicolumn{2}{|c|}{ Site 1} & \multicolumn{2}{|c|}{ Site II } \\
\hline & & $\mathbf{A}$ & B & $\mathrm{C}$ & D \\
\hline \multirow{2}{*}{1} & \multirow{2}{*}{ Wet stover weight, $\mathrm{g}$} & $352 \pm$ & $459 \pm$ & $367 \pm$ & $472 \pm$ \\
\hline & & $34.89^{\mathrm{a}}$ & $30.54^{\mathrm{b}}$ & $23.64^{\mathrm{a}}$ & $23.55^{\mathrm{b}}$ \\
\hline \multirow{2}{*}{2} & \multirow{2}{*}{ Dry Stover Weight, } & $146 \pm$ & $183 \pm$ & $150 \pm$ & $189 \pm$ \\
\hline & & $14.78^{\mathrm{a}}$ & $13.15^{\mathrm{b}}$ & $10.26^{\mathrm{a}}$ & $9.86^{\mathrm{b}}$ \\
\hline \multirow{2}{*}{3} & \multirow{2}{*}{ Dry Cob Weight, $\mathrm{g}$} & $139 \pm$ & $174 \pm$ & $142 \pm$ & $180 \pm$ \\
\hline & & $13.77^{\mathrm{a}}$ & $9.26^{\mathrm{b}}$ & $6.70^{\mathrm{a}}$ & $11.79^{\mathrm{b}}$ \\
\hline \multirow{2}{*}{4} & Weight of 100 & $28.19 \pm 2.31^{\mathrm{a}}$ & $36.19 \pm$ & $29.10 \pm$ & $36.52 \pm 1.67^{b}$ \\
\hline & seeds/cob, g & & $1.79^{\mathrm{b}}$ & $2.39^{\mathrm{a}}$ & $50.02 \pm 1.0$ \\
\hline \multirow{2}{*}{5} & \multirow{2}{*}{$\begin{array}{l}\text { Potential Wet Stover, } \\
\text { ton/ha }\end{array}$} & $13.63+0.78^{\mathrm{a}}$ & $16.00 \pm$ & $13.94 \pm$ & $16.31+0.83^{\mathrm{b}}$ \\
\hline & & & $0.98^{\mathrm{b}}$ & $0.75^{\mathrm{a}}$ & \\
\hline \multirow{2}{*}{6} & \multirow{2}{*}{$\begin{array}{l}\text { Potential Dry Stover, } \\
\text { ton/ha }\end{array}$} & & $6.38 \pm$ & $5.81 \pm$ & $6.63 \pm$ \\
\hline & & $5.75 \pm 0.29^{\circ}$ & $0.32^{\mathrm{b}}$ & $0.24^{\mathrm{a}}$ & $0.48^{\mathrm{b}}$ \\
\hline \multirow{2}{*}{7} & \multirow{2}{*}{$\begin{array}{l}\text { Potential Dry Seeds, } \\
\text { ton/ha }\end{array}$} & \multirow{2}{*}{$5.21 \pm 0.39^{\mathrm{a}}$} & $7.04 \pm$ & $5.38 \pm$ & $7.26 \pm$ \\
\hline & & & $0.42^{\mathrm{b}}$ & $0.40^{\mathrm{a}}$ & $0.35^{\mathrm{b}}$ \\
\hline
\end{tabular}

$\mathrm{A}=$ control; $\mathrm{B}=$ dryland remediated using biofertilizer enriched with plant-growth-promoting microbial inoculants. Within lines, values with differing superscripts differed significantly $(\mathrm{p}<0.05)$

The increase on both teak plant sites occurred in the weight of dry stover from 146-150 g to $183-189 \mathrm{~g}$ and the weight of 100 dry seeds from $28-29 \mathrm{~g}$ to $36 \mathrm{~g}$. Remediation treatment at both sites can improve the potential dry stover yield from approximately 5.75 ton/ha to 6.63 ton/ha (12.54\%) and increase the potential dry seeds from approximately 5.30 ton/ha to 7.15 ton/ha $(35.03 \%)$. Maize crop yield increased when the level of $\mathrm{P}$ in $\mathrm{P}_{2} \mathrm{O}_{5}$ was very low in the dryland. It is presumably related to bioorganic fertilizer that contains $\mathrm{N}$ fixation bacterial isolates (KDB2) and phosphatesolubilizing bacterial isolates (KLB5, BM5, KLBN1). These results indicate that the functional microbial consortia inoculant is suitable to use as a bioactive ingredient to produce bioorganic fertilizer. Therefore, it can improve the growth and yield of maize (Zea mays L.) variety P21 on the dryland of forest buffer. Besides, these results also indicate that dryland remediation is appropriate for improving the productive function of a dryland forest buffer.

\section{Effect of oil-sludge-contaminated soil remediation on the growth of king grass}

The remediation of oil-sludge-contaminated soil was performed by hydrocarbon-degrading functional microbial inoculants through in-situ composting. The observed plot with a size of approximately $150 \mathrm{~m}^{2}$ was divided into six $20 \mathrm{~m}^{2}$ subplots. Afterward, the six subplots were given a total of $300 \mathrm{~g}$ of hydrocarbon-degrading functional microbial inoculants, $60 \mathrm{~kg}$ of sawdust, and $3.6 \mathrm{~kg}$ of NPK fertilizer. In order to maintain the condition of composting process, the land in each plot was shaped into a mound of a height of about $20 \mathrm{~cm}$ in the middle. Then, it was covered with plastic. The composting process itself was carried out for 60 days when hydrocarbon-degrading functional microbes were inoculated. Watering and ground reversing were performed during composting period. King grass treatment was carried out for 90 days. Remediation of oil-sludge contaminated soil using $50 \mathrm{~g} / 20 \mathrm{~m}^{2}$ or $25 \mathrm{~kg} / \mathrm{ha}$ of functional microbial inoculants gave significant result on the performance of king grass growth as shown in Fig. 2.

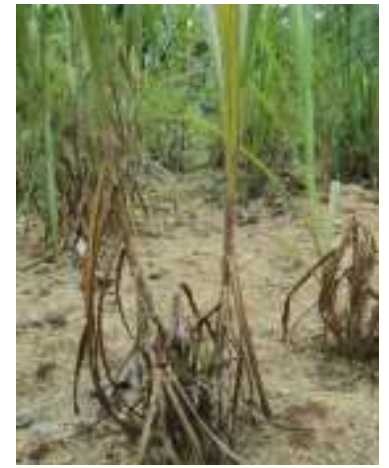

Control (A)

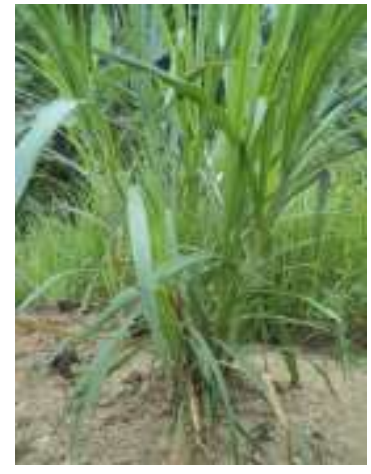

Inoculation of Microbes (B)
Fig 2. Appearance of king grass at 90 days after planting. 
The appearance of plant growth was improved by in-situ composting in oil-sludge contaminated soil for 60 days. This result was presumably caused by detoxification of rhizosphere microbial isolates against products of hydrocarbon decomposition [17]. Rhizosphere microbial isolates in the functional microbial inoculants were also supposedly able to fix $\mathrm{N}$ and dissolved phosphate for king grass growth. King grass growth of plot B $(213.97 \mathrm{~cm})$ tended to be higher than plot A $(154.54 \mathrm{~cm})$. ANOVA test showed that there was no significant difference $(p>0.05)$ in plant height. Meanwhile, other parameters indicate a significant difference $(\mathrm{p}<0.05)$ from the treatment obtained by plot A and plot B as shown in Table 5. The results suggest that the microbial inoculants consortia obtained bacterial isolates (KDB2, KLB5, BM5, KLBN1) and fungal isolates (KLF6, RK1) are appropriate to enhance the growth of king grass in the oil-sludge contaminated soil after in-situ composting. The results also indicate that landfarming treatment on oil-sludge-contaminated soil requires detoxification efforts and selection of beneficial rhizosphere microbes for plant growth [18].

Table 5. Performance of King Grass at 90 Days After Planting

\begin{tabular}{clcl}
\hline No & \multicolumn{1}{c}{ Parameter } & A & B \\
\hline 1 & Shoot height, cm & $154.54 \pm 46.26^{\mathrm{a}}$ & $213.97 \pm 38.59^{\mathrm{a}}$ \\
2 & Wet Shoot Weight, g & $211.17 \pm 82.42^{\mathrm{a}}$ & $440.53 \pm 123.63^{\mathrm{b}}$ \\
3 & Dry Shoot Weight, g & $47.39 \pm 18.50^{\mathrm{a}}$ & $100.66 \pm 28.25^{\mathrm{b}}$ \\
4 & N uptake, mg/plant & $415.53 \pm 24.41^{\mathrm{a}}$ & $913.67 \pm 25.08^{\mathrm{b}}$ \\
5 & P uptake, mg/plant & $76.52 \pm 0.15^{\mathrm{a}}$ & $178.33 \pm 6.39^{\mathrm{b}}$ \\
\hline
\end{tabular}

$\mathrm{A}=$ control $; \mathrm{B}=$ oil-sludge-contaminated soil remediated using hydrocarbon-degrading functional microbial inoculants and plantgrowth-promoting microbial inoculants. Within rows, values with differing superscript differed significantly $(\mathrm{P}<0.05)$

The remediation of oil-sludge-contaminated soil that was carried out gradually by hydrocarbondegrading functional microbial inoculants and plantgrowth-promoting functional microbial inoculants resulted in the improvement of soil quality parameters. ANOVA test results showed that organic $\mathrm{C}, \mathrm{C} / \mathrm{N}$ ratio, and TPH showed significant difference $(p<0.05)$, whereas organic matter, $\mathrm{N}$ total, and $\mathrm{pH}$ showed no significant differences $(p>0.05)$ between the treatment obtained by plot A and plot B as shown in Table 6. The in-situ composting for 60 days can reduce TPH from $105 \mathrm{~g} / \mathrm{kg}$ to $44 \mathrm{~g} / \mathrm{kg}(58.10 \%)$. The in-situ composting and king grass planting for 120 days was able to reduce TPH from $105 \mathrm{~g} / \mathrm{kg}$ to $24 \mathrm{~g} / \mathrm{kg}$ (76.75\%). Additionally, the in-situ composting and king grass planting for 120 days enriched by plant- growth-promoting functional microbial inoculants can decrease TPH from $105 \mathrm{~g} / \mathrm{kg}$ to $19 \mathrm{~g} / \mathrm{kg}$ $(82.23 \%)$. The results indicate that hydrocarbondegrading functional microbial inoculants and plantgrowth-promoting functional microbial inoculants are suitable for use in dryland remediation of oilsludge-contaminated soil by using in-situ composting and landfarming methods [11].

Therefore, the growth-promoting functional microbial inoculants are suitable as a remediation agent for improving the productive functions of dryland forest buffer upland of oil-sludgecontaminated soil. Further, the hydrocarbondegrading microbial inoculants are suitable for use in dryland remediation of oil-sludge contaminated soil by using in-situ composting and landfarming methods. Hydrocarbon-degrading microbial inoculants (BMC2, BMC4, BMC6, FMC2, FMC6) have potential to reduce TPH in soil [19].

Table 6. Soil Characteristics of Oil Sludge Contaminated Soil Remediation

\begin{tabular}{|c|c|c|c|c|c|c|}
\hline \multirow{2}{*}{$\begin{array}{l}\mathrm{N} \\
\mathrm{o}\end{array}$} & \multirow[t]{2}{*}{ Parameter } & \multicolumn{2}{|c|}{ Pre-Remediation } & \multirow{2}{*}{$\begin{array}{c}\text { Post- } \\
\text {-composting } \\
60 \text { days in- } \\
\text { situ }\end{array}$} & \multicolumn{2}{|c|}{$\begin{array}{l}\text { King grass } \\
\quad 90 \text { days } \\
\text { after planting }\end{array}$} \\
\hline & & $\begin{array}{l}\text { Non- } \\
\text { contami- } \\
\text { nated }\end{array}$ & $\begin{array}{l}\text { Hydrocarbon } \\
\text { contaminated }\end{array}$ & & A & B \\
\hline 1 & $\mathrm{pH}$ & $7.16 \pm 0.08^{\mathrm{ab}}$ & $7.67 \pm 0.13^{\mathrm{c}}$ & $7.25 \pm 0.03^{b}$ & $7.03 \pm 0.07^{\mathrm{a}}$ & $6.99 \pm 0.06^{\mathrm{a}}$ \\
\hline 2 & $\begin{array}{l}\text { Organic } \\
\text { matter, } \%\end{array}$ & $6.56 \pm 0.40^{\mathrm{a}}$ & $13.86 \pm 1.03^{\mathrm{c}}$ & $9.62 \pm 0.66^{\mathrm{b}}$ & $8.25 \pm 0.54^{\mathrm{ab}}$ & $7.86 \pm 0.51^{\mathrm{ab}}$ \\
\hline 3 & $\begin{array}{l}\text { Organic } \\
\mathrm{C}, \%\end{array}$ & $0.81 \pm 0.01^{\mathrm{a}}$ & $5.54 \pm 0.11^{\mathrm{e}}$ & $2.79 \pm 0.04^{\mathrm{d}}$ & $1.91 \pm 0.01^{\mathrm{c}}$ & $1.65 \pm 0.01^{\mathrm{b}}$ \\
\hline 4 & N Total, $\%$ & $0.17 \pm 0.17^{\mathrm{b}}$ & $0.14 \pm 0.02^{\mathrm{a}}$ & $0.16 \pm 0.01^{\mathrm{ab}}$ & $0.17 \pm 0.01^{\mathrm{ab}}$ & $0.17 \pm 0.01^{\mathrm{ab}}$ \\
\hline 5 & $\mathrm{C} / \mathrm{N}$ & $4.77 \pm 0.08^{\mathrm{a}}$ & $40.49 \pm 0.78^{\mathrm{e}}$ & $17.92 \pm 0.24^{\mathrm{d}}$ & $11.76 \pm 0.09^{c}$ & $10.08 \pm 0.04^{\mathrm{b}}$ \\
\hline 6 & $\mathrm{TPH}, \mathrm{g} / \mathrm{kg}$ & - & $104.87 \pm 2.59^{c}$ & $44.04 \pm 8.90^{\mathrm{b}}$ & $24.13 \pm 1.68^{\mathrm{a}}$ & $19.40 \pm 2.44^{\mathrm{a}}$ \\
\hline
\end{tabular}

$\mathrm{A}=$ Control, $\mathrm{B}==$ oil-sludge-contaminated soil remediated using hydrocarbon-degrading functional microbial inoculants and plantgrowth-promoting microbial inoculants, TPH $=$ Total Petroleum Hydrocarbons.

Within rows, values with differing superscript differed significantly $(\mathrm{P}<0.05)$

\section{CONCLUSION}

The irradiated-compost based microbial inoculants containing nitrogen-fixing bacterial isolates (KDB2), phosphate-solubilizing bacterial isolates (KLB5, BM5, KLBN1), and isolates of organic-matter decomposting fungi (KLF6, RK1) are appropriate to increase the productive function of dryland in the forest buffer. Remediation using organic matter enriched with functional microbial inoculants can increase the yield of maize (Zea mays L.) upland of forest buffer. Irradiated-compostbased microbial inoculants containing hydrocarbondegrading microbial isolates (BMC2, BMC4, BMC6, FMC2, FMC6) are suitable for use in the 
remediation of hydrocarbon-contaminated soil by in-situ composting method. Irradiated-compostbased microbial inoculants containing plant-growthpromoting microbial isolates can enhance king grass (Pennisetum purpureum Schumach.) growth in oil-sludge-contaminated soil using in-situ post-composting.

\section{ACKNOWLEDGMENT}

This study was supported by the Center for Isotopes and Radiation Application, Indonesian National Nuclear Energy Agency (BATAN). The author would like to acknowledge Trifika Bangun Energy Company as the operator of oil old wells at Kedewan, Cepu-Blora, and the local government of Ngasem, Bojonegoro for its permission for field experiment. The authors also greatly thank Marwadi and Arief Adhari for their technical support in the field.

\section{REFERENCES}

1. I.P. Garjita, I. Susilowati and T. Retnaningsih, Journal of Ecosciences VI (2014) 47.

2. N. Brunel, O. Seguel and E. Acevedo, J. Plant Nutr. Soil Sci. 13 (2013) 622.

3. Hafiluddin, Journal of EMBRYO 8 (2011) 47.

4. T.R.D. Larasati and N. Mulyana, Science Journal of Isotopes Application 9 (2013) 139.

5.F.F. Zhyahrial, Y.S. Rahayu and Yuliani, Journal of LenteraBio. 3 (2014) 237.

6. I. Pan, B. Dam and S.K. Sen, Journal of Biotech. 2 (2012) 127.

7. P. Marschner, Marschner's Mineral Nutrition of
Higher Plants, $3^{\text {rd }}$ ed., Academic Press, Amsterdam (2012) 684.

8. Anonymous, Biofertilizer Manual, FNCA Biofertilizer Project Group, Japan Atomic Industrial Forum, Tokyo (2009) 41.

9. T.R.D. Larasati, N. Mulyana and D. Sudrajat, Production of Vermicompost Based-Carrier to Prepare Plant Growth Promoting-Rhizosphere Bacterial Inoculants, Proceeding of Meeting and Scientific Presentations on Basic Research in Nuclear Science and Technology (2012) 201.

10. M. Chen, P. Xu, G. Zeng et al., Biotechnology Advances, Elsevier Inc. 33 (2015) 745.

11. K.H. Udiwal and V.M. Patel, International Journal of Chemical, Environmental and Pharmaceutical Research 1 (2010) 17.

12. M. Kolet, Int. J. Curr. Microbio. App. Sci. 2 (2013) 278.

13. Q. Wang, S. Zhang, Y. Li et al., Journal of Environmental Protection 2 (2011) 47.

14. F.M. Shaieb, A.H. Elghazawani and A. Issa, Int. J. Curr. Microbil. App. Sci. 4 (2015) 920.

15. W. Liu, Y. Luo, Y. Teng et al., Environ. Geochem. Health 32 (2010) 23.

16. L. Kok Chang, D. Ibrahim and I. Che Omar, Jour. of Microbiol. Research 5 (2011) 2609.

17. E. Dindar, F. Olcay, T. Sagban et al., Journal Biol. Environ. Sci. 7 (2013) 39.

18. V. Nihorimbere, M. Ongena, M. Smargiassi, et al., Biotechnol. Agron. Soc. Environ. 15 (2011) 327.

19. Y. Ming-He, X. Guo Duan and Y. Sheng Liu, J. Chem. Technol. Biotechnol. 89 (2014) 1782. 